\title{
Erratum to: Structural capacity assessment of machine-building enterprises and associations - The role of "green" technologies in the solving of strategic objectives of the Russian transport system
}

Elena Kuznetsova ${ }^{1}$, Anastasia Akulova ${ }^{1}$, and Marina Zhuravskaya ${ }^{2}$

${ }^{1}$ Mechanics and Machine Building Institute, Ural Federal University, Russia

${ }^{2}$ Ural State University of Railway Transport, Yekaterinburg, Russia

Original article:

SHS Web of Conferences 35, 01080 (2017), DOI: 10.1051/shsconf/20173501080

The title of this article is wrong. It should be replaced by the title "The role of "green" technologies in the solving of strategic objectives of the Russian transport system". 